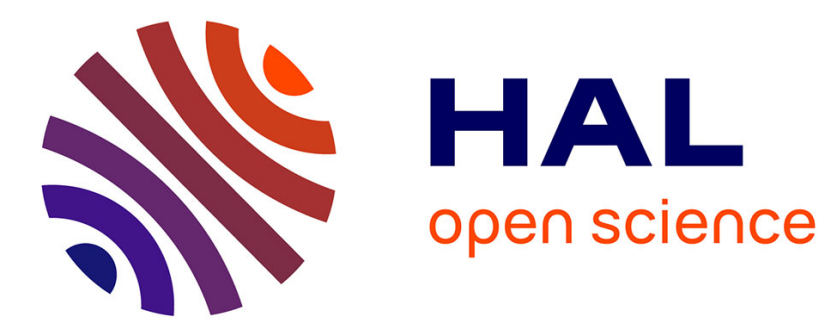

\title{
Bacterial leaf and stem blight of safflower in Pakistan
}

\author{
M. Afazal Akhtar, M. Siddique Mirza, M. Aslam
}

\section{To cite this version:}

M. Afazal Akhtar, M. Siddique Mirza, M. Aslam. Bacterial leaf and stem blight of safflower in Pakistan. Agronomie, 1987, 7 (7), pp.539-540. hal-00885024

\section{HAL Id: hal-00885024 https://hal.science/hal-00885024}

Submitted on 1 Jan 1987

HAL is a multi-disciplinary open access archive for the deposit and dissemination of scientific research documents, whether they are published or not. The documents may come from teaching and research institutions in France or abroad, or from public or private research centers.
L'archive ouverte pluridisciplinaire HAL, est destinée au dépôt et à la diffusion de documents scientifiques de niveau recherche, publiés ou non, émanant des établissements d'enseignement et de recherche français ou étrangers, des laboratoires publics ou privés. 


\title{
Bacterial leaf and stem blight of safflower in Pakistan
}

\author{
M. Afazal AKHTAR, M. Siddique MIRZA \& M. ASLAM \\ Crop Diseases Research Institute, National Agricultural Research Centre, NARC, Islamabad, Pakistan
}

SUMMARY

\begin{abstract}
Bacterial leaf and stem blight disease on safflower (Carthamus tinctorus L.) was detected in 1985 at National Agricultural Research Centre, Islamabad. The causal agent isolated from diseased plants was a rodshaped, gram-negative, motile fluorescent bacterium which was on the basis of its bio-chemical and physiological reactions, identified as Pseudomonas syringae pv. syringae van Hall. This is believed to be the first identification of this bacterium on safflower from Pakistan.
\end{abstract}

Additional key words : Pseudomonas syringae.

Une maladie bactérienne dessèchant les feuilles et les tiges du catame (Carthamus tinctorus L.) fut détectée en 1985 au Centre National de Recherche Agricole, Islamabad. L'agent causal isolé des plantes malades est une bactérie en bâtonnet, gram-négative, mobile, fluorescente qui est identifiée comme Pseudomonas syringae pv. syringae sur la base de ses réactions biochimiques et physiologiques. Il est affirmé qu'il s'agit de la première identification de cette bactérie sur Carthame au Pakistan.

Mots clés additionnels : Pseudomonas syringae.

\section{INTRODUCTION}

Bacterial leaf and stem blight incited by Pseudomonas syringae pv. syringae van Hall was observed on safflower in the germplasm evaluation experiment at National Agricultural Research Centre (NARC), Islamabad in 1985. Diseased plants showed necrotic streaks and translucent spots on leaves in the rosette stage. In severely affected plants, when split longitudinally, dark brown necrosis in pithy tissue of stem was noted. Isolations made from the diseased specimens yielded a green pigmented, gram-negative, rod-shaped motile bacterium. In California (USA), KILSIEwICZ et al. (1963) found a similar disease on safflower caused by an unnamed but apparently similar Pseudomonas. Later ERWIN et al. (1964) from California, and GNANAMANIEKAM \& KANDASWAMY (1978) from India, reported a bacterial leaf and stem blight caused by Pseudomonas syringae. However, it has not been reported earlier on safflower from Pakistan.

The objectives were to identify the causal agent on the basis of its cultural characteristics, biochemical and physiological reactions and to fulfil Koch's postulates for determining pathogenicity.

\section{MATERIALS AND METHODS}

\section{A. Isolation and identification}

Isolations were made from the water-soaked lesions on the stem and leaves of infected plants of safflower collected from NARC, Islamabad in February 1985. Diseased plant parts were washed thoroughly and small segments $(3 \mathrm{~mm})$ of advancing margins of lesions were surface-sterilized in $0.1 \mathrm{p}$. cent Chlorox, washed in sterile distilled water (SDW) and then placed on King's medium B (KB) (KING et al., 1956). Fluorescent colonies which developed after $48 \mathrm{~h}$ incubation at $25^{\circ} \mathrm{C}$ were serially sub-cultured on a $\mathrm{KB}$ medium to get pure cultures. The isolates were identified and confirmed (PALLERONI, 1984 ; KLEMENT et al., 1964 ; LELLIOTT et al., 1966) for their biochemical, physiological and hypersensitive reactions.

\section{B. Pathogenicity}

Two safflower cultivars, PI-248867 and PI-401584 (Indian), generally 4 plants per cultivar in two repli- 
cations were used in the pathogenicity tests. Inoculations were made on 4-week-old plants grown in the greenhouse. Before inoculation, plants were covered with plastic bags for $24 \mathrm{~h}$, then inoculated by injecting bacterial suspension in SDW, at absorbance 0.10 , with $10^{6}$ colony forming units $/ \mathrm{ml}$, in the petiole using a hypodermic needle. Plants inoculated with SDW were kept as controls. After inoculation, the plants along with the control were covered with polyethylene bags for $72 \mathrm{~h}$, and examined daily for disease development.

\section{RESULTS AND DISCUSSION}

\section{A. Identification}

The bacterium produced white cream coloured, smooth or rough fluorescent colonies with green diffusible pigment on KB medium. The isolates were gram-negative, aerobic, oxidative, motile, rod-shaped, measuring 0.6-1.4 $\times$ 1.5-2.0 $\mathrm{mm}$, acid from glucose, galactose, mannitol and glycerol positive, maltose and lactose negative, levan-positive, arginine dihydrolasenegative, potato rot negative, indol and $\mathrm{H}_{2} \mathrm{~S}$ negative, nitrate reduction negative, and gelatin positive (LELLIOTT et al., 1966 ; SANDS et al., 1970, 1980). The bacterium was identified as Pseudomonas syringae pv. syringae van Hall (PALLERONI, 1984). Necrotic reaction on tobacco plants further proved that the bacterium was potentially pathogenic (KLEMENT et al., 1964).

\section{B. Pathogenicity}

Pathogenicity tests were confirmed on 4-week-old safflower plants of variety PI-248867 and PI-401584. The bacterium produced typical dark brown, necrotic spots and streaks on the leaf and petiole of inoculated plants after $96 \mathrm{~h}$. More than $60 \mathrm{p}$. cent of the plants collapsed due to rotting and later died. Plants inoculated with SDW did not develop any disease symptoms. The same bacterium exhibiting identical cultural, physiological and biochemical reactions was consistantly reisolated from the necrotic spots on the inoculated plants, while no bacterium was recovered from the leaves inoculated with SDW. Pathogenicity results were similar to those of ERWIN et al. (1964) and GNANAMANIEKAM \& KANDASWAMY (1978).

Recu le 15 janvier 1987. Accepté le 6 avril 1987.

\section{REFERENCES}

Erwin D. C., Starr M. P., Desjardin P. R., 1964. Bacterial leaf and stem blight of safflower caused by Pseudomonas syringae. Phytopathology, 54, 1247.

Gnanamaniekam S. S., Kandaswamy P. R., 1978. Bacterial leaf and stem blight : a new disease of safflower in India caused by Pseudomonas syringae. Con. Sci. (India), 47, 506.

King E. O., Ward M. K., Raney D. E., 1954. Two simple media for the demonstration of pyocyanin and fluorescein. Journal Laboratory and Clinical Medicine, 44, 301-307.

Klement Z., Farkas G. L., Lovrekovich L., 1964. Hypersensitive reaction induced by phytopathogenic bacteria in tobacco leaf. Phytopathology, 54, 474-477.

Klisiewicz J. M., Houston B. R., Peterson L. J., 1963. Bacterial blight of safflower. Plant Dis. Rep., 47, 964-97.
Lelliott R. A., Billing E., Hayward A. C., 1966. A determinative scheme for the fluorescent plant pathogenic Pseudomonads. $J$. appl. Bacteriol., 29, 470-489.

Palleroni N. J., 1984. Pseudomonas. In Bergey's Manual of Systematic Bacteriology, 141-190. Williams \& Wilkins, Baltimore.

Sands D. C., Schroth M. N., Hildebrand D. C., 1970. Taxonomy of phytopathogenic pseudomonads. J. Bacteriol., 101, 9-23.

Sands D. C., Schroth M. N., Hildebrand D. C., 1980. Pseudomonads. In " Laboratory Guide for Identification of plant pathogenic Bacteria ", 36-44 (Ed. N. W. Schoad) St-Paul, Minnesota, Am. phytopathol. Soc., Monogr. 